はないかと思う。また「最盛期には，日本の約八割の大学が，紛争状態に突入し ていった」 $(82$ ページ $)$ とあるが，評者が当時の新聞や政府刊行物等を調べた限り では，1968，69年の「紛争校」の総数は 4 年制大学の $44.6 \%$ あった。これにつ いてはいつか，もとになる資料を扔教えいただければ，と思う。）

ところで最後に小谷は, 震災ボランティア, HIV 訴訟の支援活動などの「「理論 の長い腕」に頼ることなく政治や社会に関わろうとする若者たち」に着目し，そ こに新しい政治的感性の胎動をみている。「若者たちの変貌」の最後に，このよう な若者たちに着目するという視点は，評者も全面的に賛成である。ただここで問 われることは, そのような若者たちと, 社会学 (の理論)，との関係であろう。小 谷が着目する若者は, 自分の要求充足に価值をおくD・ヤンケロビッチの自己充 足的価值観と関係するように思うが，宮台真司のいう「まったりと生きる若者」 や，小林よしのり等の「大人になれ」式の言説にひかれる若者 $(9-10$ ページ) と，どのように分化してこのような若者が生まれるのかが，そこではより説明さ れる必要があるのではないかと思う。

また説明力を失った「理論の長い腕」に頼らない若者たちがでてきたことはよ いと思うが，やはり社会学 (の理論) の役割は，現象を説明し，予想を立てるこ とであるから，そのような若者たちに適合した運動の理論などに対して小谷がど のように考えているのか，もう少し聞きたかったように思う。

何か最後は，自分にとっての課題を小谷に聞いているような書評になってしま ったが，それも本書が多くの人を刺激してくれる内容に満ちているからであろう。

\title{
山本鎭雄著
}

\section{『時評家 新明正道』}

(時潮社, 1998年, A5 判, 236頁, 2,600円)

秋元 律郎

(早稲田大学教授)

異色な，しかし正統な学史研究である。ここで異色だというのは，ひとつには， 従来の研究にみられるように新明の綜合社会学の理論形成と特徴に焦点をあてて いくのではなく，いわば問題史的な設定のなかで，その位置づけと時代的な意味 を問うという手法をとっていることにある。もうひとつは，そこに「時評家」と しての新明の発言と行動をぶつけることによって，再検討の道をひらいていこう とした手続である。

そしてそれがなによりも正統だというのは, こうした視点から, 一人の社会学 者の社会観に迫り, さらに時代にたいする応答に目を凝らすことによって, 問題 を固まった理論の領域から解き放っていることである。その分析は，きわめて内 
在的・全体的な媣い理解に支えられている。

たしかに形式社会学批判以後のあらたな社会学の段階を見据えた新明の社会学 は, 戦前の日本社会学の発展にあって, 高く大きく聳え立っている。そしてそこ に凝集された驚くほどの理論的検討に接するとき，新明の企図した綜合社会学の 体系樹立の道筋じたいが，ひとつの学史的な意味をもつ。

しかし著者の意図は，そうしたこれまでの視野から，あらたな理解の次元に新 明社会学を置き換えるところにあったように思われる。著者は，これを，「一方の 極には社会学者としての新明，つまり綜合社会学の体系化を企図する理論社会学 者と, もう一方の極には同時代の混迷を深める社会状況，とくに危機を深める政 治的状況を警告する批評家としての新明が存在する」（81頁）という視角から，組 み直していく。

本書が，あえて理論形成の問題を前面に押し出すことをせず，社会史的な背景 から，たえず時代の内包する問題に主体的にかかわっていった新明の理論と行動 に目を向け，その意味を探ろうとしているのは，このためである。こうして本書 の主軸は, 新明の学生時代から関西学院教授就任時にいたるまでの思想形成の時 期，ファシズム批判と社会学体系化の過程，そして戦時にかけての東覀連盟への 参加と, 戦後期の展開におかれている。

そこには人道主義への傾倒から, 戦闘的な社会主義へ関心を高め, 実践的に 「新人会」に身をおいた新明の青年時代（第一，二章）が，大正デモクラシーとそ れに続く時代の問題性のなかで語られ, ついで形式社会学批判以後, ドイッ留学 期を中心にみせるマルクス主義への接近と知識社会学への傾斜が，つねに時代の もつ問題と切り結びながら，新明の理論形成の基盤として説き明かされていく。 そのなかにあって著者の意図がもっともよく見えてくるのが，第四章「ファシ ズム批判とその陥突」，第五章「東亜協同体と東亜連盟」である。つまり時評家と しての新明が時代にしめした発言をとおして，その社会学理論のもつ意味をとり 押さえていこうというのである。これについて著者は，「新明の東亜連盟への関与 は決して受動的ではなかった」(96頁) といい,「一個の現代の神話」といわれた 東亜協同体論に，なぜ新明がコミットしていったのか，その主体的な契機を探ろ うとしている。そしてそれは，けっして綜合社会学をささえる理念と乘離したも のではなかったとみている。「新明は, 社会学研究の現在的課題を新体制建設に寄 与すべきとした。綜合社会学の提唱者としての新明と批評家としての新明，つま り新明に拈ける価值的評価と科学的認識は一体化し，東业新体制建設のために， 彼の精力のすべてを傾注した」(125頁) という。

どうしてファシズムに批判的な立場をとりつづけてきた新明が，東亜の「永遠 なる和平の組織」を夢み，また軍閥と官僚を制御しようと意図した過程で，かえ って隘路におちこんでいったのか。著者の表現を借りれば，「ミイラ取りが，ミイ ラになる」経緯が，ここで多くの頁をさいて言及されていくことになる。これを 扱った第五章が，東亜協同体思想と東业連盟の研究として，独立した価值をもつ 
ほどの内容をそなえているのは，こうした著者の問題への切り达み方によるもの といってよい。

そしてこの問題は，当然のことながら新明のおち込んだファシズム批判の陥穷 と錯誤，つまり「転向」の問題に向けられていく。ここで著者が求めているのは, 単純な善悪の基準ではなく，「むしろ転向の契機と仕方に着目し，そこから何を主 体的に明らかにすべきか」（136頁）を問うことにある。本書で，「思想的転換の 軌跡」(第七章) が，もっとも論争的な性格をもっているのは，それが新明個人を こえた転向という現代日本の思想史に突き刺った問題を，どう解釈していくかと いう視座の設定と染くかかわるからである。いうまでもなくわれわれに投げかけ られた課題も，ここにある。そして戦後ドイツにおいて，ワイマール期から戦時 期にかけての社会学の位置づけと歴史的評価について, 激しい論争がおこなわれ てきたことを思い出すとき，本書は，たんなる新明研究というよりは，多くの示 唆と問題性に富んだひとつの学史研究だといわなければならないだろう。

富永健一・宮本光晴編著

\section{『モビリティ社会への展望』}

(慶應義塾大学出版会, 1998年, 四六判, 295頁, 3,500円)

\section{平田 周一}

(日本労働研究機構)

本書は，二人の編著者が中心となっている経済社会学会のワークショップのメ ンバーによる成果をまとめたものである。序文にあるとおり，本書に論文を寄せ ている研究者は多岐にわたり，社会学だけでなく経済学のプロパーもいる。した がって, 内容も多彩で書評に与えられたスペースの中で本書の全体を紹介するこ とはできない。しかし，序文によれば，本書の大きな目的は，「いま日本が直面し つつある社会変動の最も顕著なものの一つ, 『日本型雇用システム』の変動という 問題を採り上げ，これを労働移動ないし職業移動という面から多角的にとらえる

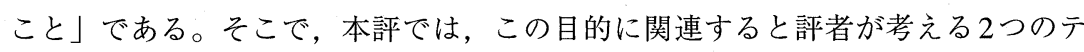
ーマに絞って論評したい。

最初のテーマは企業組織における雇用慣行に関する研究と, 社会移動に関する 研究の統合である。この二つのテーマは, それぞれ独自に, 多くの実証的な研究 成果が蓄積されてきている。日本の雇用制度については, 多くの労働経済学者に よって, その特徴とされてきた終身雇用, 年功制度, 企業内訓練などの慣行に関 する研究が盛んに行われてきた。社会学の分野でも, ローゼンバウムの企業内の 昇進構造の研究による刺激もあって, 企業内労働市場における移動に関する研究 がおこなわれるようになり，実証的な研究成果も蓄積されてきた。 